\title{
Ketepatan Pengaruh Manajemen Logistik Terhadap Tingkat Kepuasan Pelanggan PT. Bhinneka Bajanas Cabang Cikarang
}

\author{
Yosephyn Patria Larici ${ }^{1}$, Fino Wahyudi Abdul ${ }^{2}$ \\ Institut Ilmu Sosial dan Manajemen Stiami \\ yosephynpatria27@gmail.com ${ }^{1}$, finowahyudi71@gmail.com ${ }^{2}$
}

\section{ARTICLE INFO}

\section{Article History}

Received : 24 Oktober 2019

Reviewed : 10 Oktober 2019

Published : 31 Oktober 2019

Available Online : 2 November 2019

\section{Keywords}

Manajemen Logistik,

Kepuasan Pelanggan

\section{Keywords}

Logistics Management, Customer Satisfaction

\begin{abstract}
Penelitian ini bertujuan untuk mengetahui seberapa besar pengaruh manajemen logistik terhadap tingkat kepuasan pelanggan PT. Bhinneka Bajanas Cab. Cikarang. Populasi penelitian ini adalah pelanggan PT. Bhinneka Bajanas Cabang Cikarang sebanyak 100 orang, sedangkan sampel dalam penelitian ini sebanyak 50 orang dengan menggunakan metode Accident Sampling, Kemudian data diolah dengan analisis regresi liniear sederhana Variabel independen pada penelitian ini adalah manajemen logistik dan variabel dependent adalah kepuasan pelanggan. Hasil penelitian ini menunjukan bahwa manajemen logistik memiliki pengaruh terhadap kepuasan pelanggan. Hal tersebut dapat dilihat dari hasil uji t yang Hasil analisis menunjukkan nilai $\mathrm{t}$ hitung > t tabel $(6,327>2,01)$. Hal ini berarti Ho ditolak dan H1 diterima, atau terdapat pengaruh (secara parsial) antara Manajemen Logistik terhadap Tingkat Kepuasan Pelanggan.
\end{abstract}

This study aims to determine how much influence logistics management has on the level of customer satisfaction at PT. Bhinneka Bajanas Cabang Cikarang. The population of this research is PT. Bhinneka Bajanas Cabang Cikarang customers as many as 100 people, while the sample in this study were 50 people using the Accident Sampling method, then the data was obtained by simple linear regression analysis. The independent variable in this study is logistical management and the dependent variable is customer's satisfaction. The results of this study indicate that logistics management has an influence on customer satisfaction. It can be seen from the results of $T$ test, the analysis' results show the value of $T$ count $>T$ table (6.327> 2.01). It means that $H O$ is rejected and $\mathrm{H} 1$ is accepted, or there is an effect (partially) between Logistics Management and Customer Satisfaction Levels.

\section{PENDAHULUAN}

Dalam dunia usaha setiap perusahaan selalu berupaya untuk memperoleh keberhasilan, mendapatkan keuntungan (Profit), dan memperluas jaringan (Network) sehingga setiap perusahaan dapat mengukur sejauh mana perusahaan tersebut dapat bersaing dengan para competitornya untuk menarik minat pembelinya, salah satunya adalah PT. Bhinneka Bajanas. Untuk itu PT. Bhinneka Bajanas selalu berupaya menjaga dan memperbaiki aktivitas manajemen logistik di perusahaan dengan memberikan pelayanan kepada pelanggannya, sehingga menciptakan kepuasan kepada pelanggan pada saat bertransaksi dengan PT. Bhinneka Bajanas. Dalam hal ini PT. Bhinneka Bajanas menekankan beberapa variabel yang harus benar-benar di perhatikan, dan salah satunya adalah masalah manajemen logistik.

Manajemen Logistik merupakan hal terpenting dalam melaksanakan suatu proses rantai suplai, dan dimana dalam proses rantai suplai ini berfungsi merancang, menjalankan, mengawasi secara efektif dan efisien proses pengadaan, pengelolaan, penyimpanan barang, pelayanan, dan informasi dari titik awal hingga titik akhir dengan tujuan untuk memenuhi kebutuan pelanggannya dan meningkatkan kepuasan pelanggannya. Dalam Siagian dan Yolanda (2005), Stock dan Lambert menjelaskan mengenai aktivitas manajemen Logistik. 
Pertama, adanya Input ke proses logistik yang terdiri dari (i) Sumber Daya Alam (Tanah, Fasilitas, dan Perlatan), (ii) Sumber Daya Manusia, (iii) Dana atau Keuangan, (iv) Informasi, Kedua, dibutuhkan beberapa strategi, yaitu dalam bentuk Output logistik. Dimana Output ini terdiri dari, (i) keunggulan bersaing untuk organisasi sebagai hasil dari orientasi pasar dan kegiatan efisiensi dan efektifitas dari operasional, (ii) kegunaan waktu dan tempat yang optimal, (iii) pergerakan ke konsumen yang efisien, Jika ketika hal tersebut dapat diperoleh, hal ini menjadi asset bagi perusahaan dan konsumen akan loyal terhadap perusahaan; akibatnya (iv) Image perusahaan meningkat.

Logistik merupakan bagian dari Supply Chain Manajemen di mana logistik merupakan bagian odari proses rantai suplai yang berfungsi merencanakan, melaksanakan, mengontrol secara efektif, efisien pergerakan dari titik awal (Point Of Origin) hingga ke titik akhir atau ke titik konsumsi (Point Of Consumption) dengan tujuan untuk memenuhi kebutuhan konsumen (Siagian \& Yolanda, 2005)

Dalam melaksanakan transaksi penjualan, PT. Bhinneka Bajanas sebagai perusahaan Trading yang menjual jenis produk baja, memerlukan manajemen logitik sehingga dapat mengatur dan mengawasi aliran barang, uang dan informasi dari titik awal hingga sampai kepada pelanggannya. PT Bhinneka bajanas menyadari bahwa manajemen logistiknya masih ada kekurangan dan perlu adanya perbaikan, baik dari aktivitas input logistik berupa pengendalian produknya, maupun dari aktivitas outputnya yang langsung bersentuhan kepada pelanggannya, dalam penelitian ini akan memfokuskan dalam melihat aktivitas output manajemen logistik dimana masih banyak aktivitas output yang harus diperbaiki oleh perusahaan yaitu kualitas produk yang ditawarkan, jasa pelayanan, kecepatan dalam proses pemesanan, kecepatan dalam memberikan informasi produk, kecepatan dalam pengiriman pesanan, kemudahan mendatangi lokasi dan kenyamanan tempat saat melakukan transaksi pemesanan, dengan adanya perbaikan diharapkan dapat mengangkat citra perusahaan dimata pelanggannya serta meningkatkan kepuasan pelanggannya.

PT Bhinneka Bajanas telah memiliki Sistem Data produk, berupa Sistem Informasi Bhinneka Bajanas. Dalam sistem tersebut memuat informasi tentang data produk, dimulai dari cek stok produk, dan potong stok produk, halaman jadwal pengiriman. Dengan adanya sistem informasi, diharapkan perusahaan dapat selalu mengedepankan kepuasan pelanggannya dengan memberikan kemudahan dalam bertransaksi baik berupa kemudahan informasi, pelayanan dan kemudahan dalam transaksi perdagangan serta meningkatkan kepuasan pelanggan PT. Bhinneka Bajanas.

Kepuasan Pelanggan adalah faktor paling penting yang sangat dijaga oleh perusahaan karena kepuasan pelanggan merupakan faktor penentu bahwa suatu perusahaan berhasil menarik konsumennya untuk membeli produk yang ditawarkan oleh perusahaan. Masih banyak perusahaan yang tidak terlalu memperhatikan kepuasan pelanggannya. Kepuasan Pelanggan merupakan ekspresi atau tingkat perasaan konsumen setelah mendapatkan sesuatu yang diinginkan dan membandingkannya dengan apa yang di terimanya. Untuk itu setiap perusahaan perlu menjaga kepuasan pelanggan dan meningkatkan tingkat kepuasan pelanggannya agar produk yang di pasarkan oleh perusahaan dapat meningkatkan tingkat penjualan di perusahaan tersebut dan membangun citra perusahaan yang baik dimata pelanggannya.

Menurut Kotler (2000), Kepuasan adalah tingkat perasaan seseorang setelah membandingkan kinerja atau hasil yang dia rasakan di bandingkan dengan harapannya. Kualitas pelayanan yang baik menjadi pembeda dalam melayani pelanggan di masing-masing perusahaan (Abdul \& Iridiastadi., 2018). Selain itu, salah satu nilai tambah bagi suatu perusahaan adalah bagaimana perusahaan membangun hubungan dengan para pelanggan (Abdul \& Purwatmini, 2018). Masih menurut (Tjiptono, 2014), Indikator yang digunakan untuk Variabel Kepuasan Pelanggan adalah: Pelayanan sesuai dengan harapan pelanggan, Kesediaan pelanggan untuk merekomendasikan kepada orang lain, Puas atas kualitas pelayanan yang sudah dirasakan.

Dalam beberapa penelitian terdahulu, bahwa kegiatan Logistik di bidang retail, salah satunya di Giant Ekstra yaitu meliputi perencanaan, pengorganisasian, pengawasan, pengadaan, pencatatan, penggudangan, pendistribusian, dan penghapusan dimana kegiatan logistik di giant ekstra dilakukan oleh berbagai divisi terkait dan kegiatan manajemen logistik ini dilakukan untuk memperlancar arus barang sehingga penjualan dapat berjalan dengan baik (Utami \& Sitorus, 2015). Remenusa (2013), menunjukkan bahwa secara simultan atau secara bersama-sama kualitas layanan dan kepuasan terhadap loyalitas pelanggan secara bersama-sama adalah positif dan kuat yang artinya apabila ada peningkatan untuk kualitas layanan dan kepuasan pelanggan maka akan adanya peningkatan terhadap loyalitas pelanggan. Menurut Hendry dan Ericko (2015), menyatakan bahwa logistic service quality ternyata memiliki pengaruh terhadap kepuasan dan loyalitas konsumen, dengan studi kasus pada gerai fast food Kentucky Fried Chicken di kota Surabaya. 
PT. Bhinneka Bajanas merupakan salah satu distributor baja kelas tinggi yang memiliki tujuan untuk melayani berbagai industri lokal dan multinasional. Sebagai agen tunggal Bohler untuk Pasar Indonesia, yang fokus pada penjualan produk Baja Bohler High Grade Special dengan kualitas standar Eropa yang konsisten. Maka perlu untuk meningkatkan Kepuasan Pelanggan PT Bhinneka Bajanas menyediakan Baja kelas tinggi dengan fasilitas In-house berstandar Internasional, termasuk fasilitas Cutting, Heat Treatment, dan Machining dengan kualitas yang konsisten. PT Bhinneka Bajanas selalu berusaha mengupayakan menciptakan kepuasan pelanggannya sehingga pelanggan akan selalu menggunakan produk dan jasa yang di tawarkan oleh perusahaan. Semua perusahaan berlomba-lomba untuk menjaga dan menciptakan kepuasan pelanggan karena kepuasan pelanggan dapat meningkatkan keunggulan dalam persaingan.

\section{METODE PENELITIAN}

Penelitian ini adalah penelitian deskriptif dengan menggunakan pendekatan kuantitatif. Pendekatan kuantitatif adalah penelitian ilmiah yang sistematis terhadap bagian-bagian dan fenomena serta hubunganhubungannya. Subjek Penelitian dengan judul Pengaruh Manajemen Logistik terhadap Tingkat Kepuasan Pelanggan PT. Bhinneka Bajanas Cabang Cikarang merupakan pelanggan PT. Bhinneka Bajanas per Maret 2019 yang berjumlah 100 pelanggan dengan sampel sebanyak 50 pelanggan. Metode samplingnya adalah accident sampling.

Pada penelitian ini data yang diperoleh dengan kuesioner yang diisi oleh pelanggan PT. Bhinneka Bajanas saat melakukan transaksi di PT. Bhinneka Bajanas Cabang Cikarang kuesioner merupakan teknik pengumpulan data dengan cara memberikan pernyataan-pernyataan tertulis kepada responden. Dalam penyebaran kuesioner dengan menyebar 100 kuesioner, setiap responden di harapkan dapat mengisi pernyataan yang telah disediakan pada kuesioner untuk diisi dengan keadaan yang sebenar-benarnya. di laksakan selama lima bulan ( 5 bulan) terhitung sejak bulan Februari 2019 dimulai dengan persiapan penelitian hingga bulan Juni 2019 dengan penyusunan laporan penelitian. Pengumpulan data kuantitatif pada penelitian ini dilakukan dengan cara penyebaran kuesioner dengan pelanggan PT. Bhinneka Bajanas Cabang Cikarang sebagai responden dalam pengisian kuesioner.

\section{HASIL PENELITIAN}

Deskripsi karakteristik responden adalah menguraikan dan memberikan gambaran mengeai identitas responden dalam penelitian ini. Adapun karakteristik responden dalam penelitian ini meliputi Usia, Jenis Kelamin, Kategori Pelanggan, dan Lama Berlangganan yang dapat di gambarkan pada tabel karateristik responden berdasrkan usia, jenis kelamin, kategori pelanggan dan lama berlangganan.

\subsection{Karakteristik responden berdasarkan usia}

Pelanggan yang bertransaksi dengan PT. Bhinneka Bajanas memiliki usia yang bervariasi dimana karakteristik responden berdasarkan usia dijadikan acuan untuk dapat memperoleh data dan bertujuan untuk mengetahui usia dominan pelanggan bertransaksi dengan PT. Bhinneka Bajanas Cab. Cikarang. Karateristik responden berdasarkan usia ditunjukkan oleh Tabel 1 berikut:

Tabel 1. Karakteristik responden berdasarkan usia

\begin{tabular}{ccc}
\hline Usia & Jumlah & Presentase ( \% ) \\
\hline$<20$ Thn & 2 & $4 \%$ \\
\hline $20-29$ Thn & 29 & $58 \%$ \\
\hline $30-40$ Thn & 11 & $22 \%$ \\
\hline$>40$ Thn & 8 & $16 \%$ \\
\hline Total & 50 & $100 \%$ \\
\hline
\end{tabular}

Sumber: Data diolah, tahun 2019 
Dari Tabel 1 diatas dapat dilihat dan diketahui karateristik responden berdasarkan usia cukup bervariasi berkisar antara usia $<20$ tahun berjumlah 2 orang dengan presentase (4\%), 20-29 tahun berjumlah 29 orang dengan presentase (58\%), 30-40 tahun berjumlah 11 orang dengan presentase (22\%), dan usia > 40 tahun berjumlah 8 orang dengan presentase (16\%). Hal ini menunjukkan bahwa pelanggan PT. Bhinneka Bajanas Cabang Cikarang bermacam usia dan sebagian besar pelanggan PT. Bhinneka Bajanas Cabang Cikaranng didominasi dengan pelanggan muda dengan kisaran umur antara 20-29 tahun yang berjumlah 29 orang dengan presentase $(58 \%)$.

\subsection{Karakteristik responden berdasarkan jenis kelamin}

Pelanggan yang bertransaksi dengan PT. Bhinneka Bajanas bervariasi jenis kelaminnya. Karakteristik berdasarkan jenis kelamin dijadikan acuan untuk dapat memperoleh data dan bertujuan untuk mengetahui pelanggan PT. Bhinneka Bajanas di dominasi oleh pelanggan laki-laki atau perempuan, karateristik responden berdasarkan jenis kelamin ditunjukkan oleh Tabel 2 berikut:

Tabel 2. Karakteristik responden berdasarkan jenis kelamin

\begin{tabular}{lcc}
\hline \multicolumn{1}{c}{ Jenis Kelamin } & Jumlah & Presentase \\
\hline Laki-Laki & 24 & $48 \%$ \\
\hline Perempuan & 26 & $52 \%$ \\
\hline Total & 50 & $100 \%$
\end{tabular}

Sumber: Data diolah, tahun 2019

Dari Tabel 2 diatas dapat dilihat dan diketahui karakteristik responden berdasarkan jenis kelaminyan terdiri atas responden laki-laki yang berjumlah 24 orang dengan presentase sebesar (48\%) dan responden perempuan yang berjumlah 26 orang dengan presentase sebesar (52\%), dari data tersebut dapat disimpulkan bahwa pelanggan yang bertransaksi di PT Bhinneka Bajanas didominasi oleh perempuan yang berjumlah 26 orang dengan presentase sebesar $(52 \%)$.

\subsection{Karakteristik responden berdasarkan kategori pelanggan}

Kategori pelanggan di jadikan salah satu acuan dalam kuesioner yang bertujuan untuk mengelompokan pelanggan PT. Bhinneka Bajanas dan memperoleh data pelanggan PT Bhinneka Bajanas lebih didominasi oleh pelanggan perorangan atau pelanggan corporate. Karakteristik responden berdasarkan kategori pelanggan ditunjukkan oleh Tabel 3 berikut:

Tabel 3. Karateristik responden berdasarkan kategori pelanggan

\begin{tabular}{|c|c|c|}
\hline Kategori Pelanggan & Jumlah & Presentase $(\%)$ \\
\hline Perorangan & 13 & $26 \%$ \\
\hline Corporate & 37 & $74 \%$ \\
\hline Total & 50 & $100 \%$ \\
\hline
\end{tabular}

Dari Tabel 3 diatas dapat dilihat dan diketahui karateristik responden berdasarkan kategori pelanggan terdiri atas dua kategori yaitu pelanggan perorangan sebanyak 13 pelanggan dengan presentase (26\%) dan pelanggan corporate sebanyak 37 pelanggan dengan presentase sebesar $(74 \%)$, dan dari data tersebut dapat diketahui bahwa pelanggan PT. Bhinneka Bajanas Cabang Cikarang didominasi oleh kategori pelanggan corporate.

\subsection{Karakteristik responden berdasarkan lama berlangganan}

Lama berlangganan merupakan kategori yang dijadikan acuan PT. Bhinneka Bajanas Cabang Cikarang untuk dapat memperoleh data yang bertujuan untuk melihat berapa lama pelanggan sudah bertransaksi dengan PT. Bhinneka Bajanas Cabang Cikarang. Karateristik responden berdasarkan lama berlangganan dapat dilihat pada Tabel 4 berikut:

Tabel 4. Karakteristik responden berdasarkan lama berlangga
\begin{tabular}{lll}
\hline Lama Berlangganan & Jumlah & Presentase $(\%)$ \\
\hline$<5$ thn & 32 & $64 \%$ \\
\hline $5-10$ thn & 18 & $36 \%$ \\
\hline $11-15$ thn & 0 & 0 \\
\hline$>15$ thn & 0 & 0 \\
\hline Total & 50 & $100 \%$ \\
\hline
\end{tabular}


Sumber: Data diolah, tahun 2019

Dari Tabel 4 diatas dapat dilihat dan diketahui karakteristik responden berdasarkan lama belangganan dengan PT. Bhinneka Bajanas. Dari data ini dapat dilihat bahwa pelanggan PT. Bhinneka Bajanas memiliki masa berlangganan yang bervariasi berkisar $<5$ thn, 5-10 thn, 11-15thn, dan $>15$ thn, dari tabel ini juga dapat dilihat bahwa pelanggan PT. Bhinneka Bajanas di dominasi pelanggan dengan lama berlangganan <5thn dengan jumlah 32 pelanggan dengan besaran presentase (64\%), sedanglan pelanggan dengan lama berlangganan kisaran 5-10 thn berjumlah 18 pelanggan dengan besaran presentase (36\%).

\subsection{Tanggapan responden pada variabel manajemen logistik}

Untuk Mengetahui pengaruh manajemen logistik di PT. Bhinneka Bajanas Cabang Cikarang khususnya dalam artian Ouput dimana langsung berhubungan dengan pelanggan, diukur dengan menggunakan dimensidimensi variabel manajemen logistik, seperti: a) Keunggulan Bersaing, b) Kegunaan Waktu dan Tempat, c) Kecepatan Pengiriman, dan d) Citra Perusahaan.

Dimensi variabel manajemen logistik ini menjadi acuan dalam membuat penyataan kuesioner penelitian yang telah disebar, dan kemudian selanjutnya jawaban kuesioner disajikan berupa tabel, hasil pengolahan data adalah diperlihatkan pada Tabel 5 (Rekapitulasi variabel manajemen logistik).

Tabel 5. Rekapitulasi variabel manajemen logistik

\begin{tabular}{|c|c|c|c|}
\hline No & Indikator & Nilai & Interpretasi \\
\hline 1 & $\begin{array}{l}\text { Produk yang dijual PT. Bhinneka } \\
\text { Bajanas lebih unggul dibandingkan } \\
\text { dengan competitor }\end{array}$ & 4,04 & Baik \\
\hline 2 & $\begin{array}{l}\text { Jasa layanan tambahan yang } \\
\text { diberikan PT. Bhinneka Bajanas } \\
\text { lebih unggul dibandingkan dengan } \\
\text { competitor }\end{array}$ & $3,58 *$ & Baik \\
\hline 3 & $\begin{array}{l}\text { Karyawan PT. Bhinneka Bajanas } \\
\text { cepat dalam menyampaikan } \\
\text { informasi tentang produk yang } \\
\text { dijual }\end{array}$ & 3,8 & Baik \\
\hline 4 & $\begin{array}{l}\text { Karyawan PT. Bhinneka Bajanas } \\
\text { cepat dalam memproses transaksi } \\
\text { pesanan produk yang dijual }\end{array}$ & 3,8 & Baik \\
\hline 5 & $\begin{array}{l}\text { PT. Bhinneka Bajanas memberikan } \\
\text { kenyamanan tempat dalam } \\
\text { bertransaksi dan mengambil } \\
\text { produk pesanan }\end{array}$ & $3,54 *$ & Baik \\
\hline 6 & $\begin{array}{l}\text { PT. Bhinneka Bajanas cepat dalam } \\
\text { pengiriman produk yang dijual } \\
\text { sampai ketangan pelanggan }\end{array}$ & $3,54 *$ & Baik \\
\hline 7 & $\begin{array}{l}\text { PT. Bhinneka Bajanas selalu sesuai } \\
\text { dan jumlah dalam pengiriman } \\
\text { produk yang dijual sampai } \\
\text { ketangan pelanggan }\end{array}$ & 3,86 & Baik \\
\hline 8 & $\begin{array}{lr}\text { PT. Bhinneka } & \text { Bajanas dapat } \\
\text { menciptakan } & \text { kepercayaan } \\
\text { pelanggan dalam membeli produk } \\
\text { yang dijual }\end{array}$ & 4,00 & Baik \\
\hline 9 & $\begin{array}{lll}\text { Kesan yang diberikan PT. } & \text { PT. } \\
\text { Bhinneka Bajanas dalam } & \text { hal } \\
\text { pelayanan sangat baik } & & \\
\end{array}$ & 3,90 & Baik \\
\hline \multicolumn{2}{|c|}{$\begin{array}{l}\text { Rata-Rata Penafsiran } \\
=\frac{34,06}{9}=3,78\end{array}$} & 34,06 & Baik \\
\hline
\end{tabular}

Dari hasil rekapitulasi Tabel 5 diatas diperoleh bahwa untuk interpretasi keseluruhan indikator adalah Baik dengan nilai tertinggi diperoleh dari pernyataan Produk yang dijual PT. Bhinneka Bajanas lebih unggul dibandingkan dengan competitor dengan jumlah 4,04 dan nilai terendah diperoleh dari pernyataan PT. 
Bhinneka Bajanas memberikan kenyamanan tempat dalam bertransaksi dan mengambil produk pesanan dan PT. Bhinneka Bajanas cepat dalam pengiriman produk yang dijual sampai ketangan pelanggan dengan jumlah 3,54. Sehingga pada skala interval ini telah ditentukan bahwa hasil angka penafsiran untuk variabel manajemen logistik sebesar 3,78 dan angka tersebut termasuk dalam skala 3,41 - 4,20 dengan kriteria penilaian Baik.

\subsection{Tanggapan responden pada variabel kepuasan pelanggan}

Untuk meningkatkan kepuasan pelanggan PT. Bhinneka Bajanas Cabang Cikarang berupaya untuk memperbaiki dan memberikan pelayanan yang baik. Karena kepuasan pelanggan merupakan suatu acuan PT. Bhinneka Bajanas sehingga dapat memperluas pasar. Kepuasan pelanggan diukur dengan menggunakan dimensi-dimensi variabel kepuasan pelanggan, seperti: a) Kualitas Produk, b) Kualitas Pelayanan, c) Emosional, d) Harga, e) Biaya.

Dimensi variabel kepuasan pelanggan ini menjadi acuan dalam membuat penyataan kuesioner penelitian yang telah disebar, dan kemudian selanjutnya jawaban kuesioner disajikan berupa tabel. hasil pengolahan data adalah diperlihatkan pada Tabel 6 (Rekapitulasi tanggapan responden pada variabel kepuasan pelanggan).

Tabel 6. Rekapitulasi tanggapan responden pada variabel kepuasan pelanggan

\begin{tabular}{|c|c|c|c|}
\hline No & Indikator & Nilai & Interpretasi \\
\hline 1 & $\begin{array}{l}\text { Kondisi produk yang dijual PT. } \\
\text { Bhinnka Bajanas dalam kondisi } \\
\text { baik hingga sampai ketangan } \\
\text { pelanggan }\end{array}$ & 4,06 & Baik \\
\hline 2 & $\begin{array}{l}\text { Umur Pakai produk yang dijual PT. } \\
\text { Bhinneka Bajanas lama ( tahan } \\
\text { lama) }\end{array}$ & 4,22 & Sangat Baik \\
\hline 3 & $\begin{array}{l}\text { PT. Bhinneka Bajanas memberikan } \\
\text { kejelasan mengenai informasi } \\
\text { barang yang dijual }\end{array}$ & 3,96 & Baik \\
\hline 4 & $\begin{array}{l}\text { Mudah dalam proses pemesanan } \\
\text { barang di PT. Bhinneka Bajanas }\end{array}$ & 4,00 & Baik \\
\hline 5 & $\begin{array}{l}\text { PT. Bhinneka Bajanas dapat } \\
\text { menciptakan rasa bangga } \\
\text { pelanggannya karena telah membeli } \\
\text { produk yang ditawarkan }\end{array}$ & 3,96 & Baik \\
\hline 6 & $\begin{array}{l}\text { PT. Bhinneka Bajanas dapat } \\
\text { menciptakan rasa bangga } \\
\text { pelanggannya karena telah membeli } \\
\text { produk dari perusahaan yang } \\
\text { bonafit }\end{array}$ & $\begin{array}{l:l}t, 96 \\
i\end{array}$ & Baik \\
\hline 7 & $\begin{array}{l}\text { PT. Bhinneka Bajanas dapat } \\
\text { menciptakan loyalitas pelanggan } \\
\text { terhadap produk yang dijual dan } \\
\text { perusahaan }\end{array}$ & \begin{tabular}{|l|l} 
& 3,86 \\
& \\
\end{tabular} & Baik \\
\hline 8 & $\begin{array}{l}\text { Harga barang yang ditawarkan PT. } \\
\text { Bhinneka Bajanas lebih murah } \\
\text { dibandingkan competitor }\end{array}$ & $2,98 *$ & Cukup Baik \\
\hline 9 & $\begin{array}{l}\text { Prosedur pembuatan nota tagihan di } \\
\text { PT. Bhinneka Bajanas lebih cepat } \\
\text { dibandingkan competitor }\end{array}$ & $3,20^{*}$ & Baik \\
\hline 10 & $\begin{array}{l}\text { PT. Bhinneka Bajanas memberikan } \\
\text { janka waktu pembayaran tagihan } \\
\text { fleksibel sesuai dengan prosedur }\end{array}$ & $\begin{array}{l:l}4,06 \\
\end{array}$ & Baik \\
\hline \multicolumn{2}{|c|}{$\begin{array}{l}\text { Rata- Rata Penafsiran } \\
=\frac{38,26}{10}=3,8\end{array}$} & 38,26 & Baik \\
\hline
\end{tabular}

*Jumlah nilai pertanyaan dibawah rata-rata penafsiran 
Dari perhitungan rekapitulasi tabel diatas diperoleh bahwa untuk interpretasi keseluruhan indikator adalah Baik dengan nilai tertinggi diperoleh dari pernyataan Umur Pakai produk yang dijual PT. Bhinneka Bajanas lama ( tahan lama) dengan jumlah 4,22 dan nilai terendah diperoleh dari pernyataan Harga barang yang ditawarkan PT. Bhinneka Bajanas lebih murah dibandingkan competitor dengan jumlah 2,98. Sehingga pada skala interval ini telah ditentukan bahwa hasil angka penafsiran untuk variabel kepuasan pelanggan sebesar 3,8 dan angka tersebut termasuk dalam skala 3,41 - 4,20 dengan kriteria penilaian Baik.

\subsection{Uji korelasi}

Tabel 7. Uji Korelasi

\begin{tabular}{|c|c|c|c|}
\hline \multicolumn{4}{|c|}{ Model Summary } \\
\hline Model R & R Square & $\begin{array}{l}\text { Adjusted } \\
\text { Square }\end{array}$ & $\begin{array}{l}\text { RStd. Error of } \\
\text { the Estimate }\end{array}$ \\
\hline $.594^{\mathrm{a}}$ & 353 & .340 & 2.182 \\
\hline
\end{tabular}

a. Predictors: (Constant), $\mathrm{x}$ (manajemen logistik)

Sumber : Hasil Olah Data SPSS 24

Hasil penghitungan Tabel 7 di atas menunjukkan nilai Koefisien Korelasi (R) sebesar 0,594. Nilai tersebut menunjukkan bahwa pengaruh variabel Manajemen Logistik adalah terhadap Tingkat Kepuasan Pelanggan adalah kuat.

\subsection{Uji koefisien determinasi}

\section{Model Summary}

Tabel 8. Uji Koefisien Determinasi

\begin{tabular}{lllll} 
Model & R & R Square & $\begin{array}{l}\text { Adjusted } \\
\text { Square }\end{array}$ & $\begin{array}{c}\text { RStd. Error of the } \\
\text { Estimate }\end{array}$ \\
\hline $.594^{\mathrm{a}}$ & .353 & .340 & 2.182 \\
\hline
\end{tabular}

a. Predictors: (Constant), $\mathrm{x}$ (manajemen logistik)

Sumber: Hasil Olah Data SPSS 24

Koefisien determinasi $\left(R^{2}\right)$ (Tabel 8) menunjukkan nilai $R^{2}=0,353$. Artinya variabel Manajemen Logistik (X) dapat menerangkan atau menjelaskan Tingkat Kepuasan Pelanggan (Y) sebesar 35,3\%, sisanya sebesar $64,7 \%$ (dari penghitungan 100\%-35,3\%) dipengaruhi oleh variabel lain yang tidak termasuk dalam model atau persamaan pada penelitian ini.

\subsection{Uji T}

Tabel 9. Uji Hipotesis $\mathrm{t}$

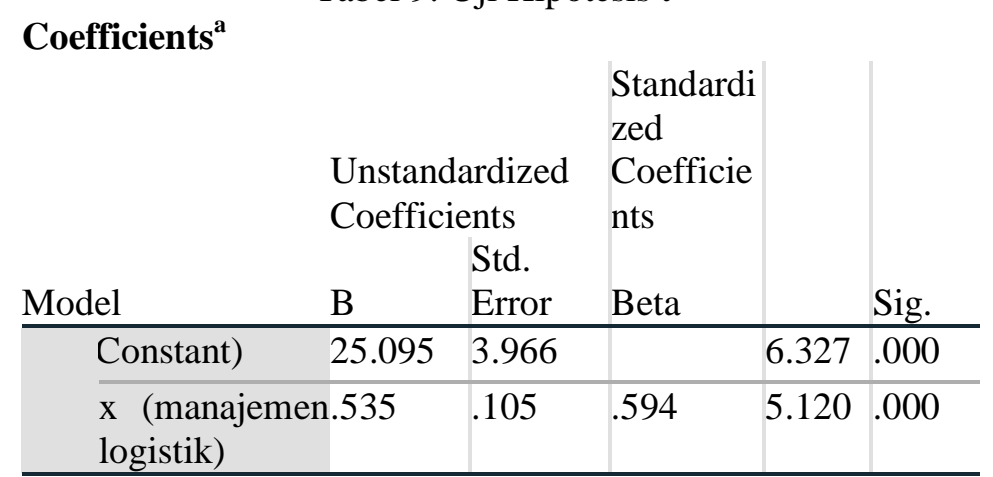

a. Dependent Variable: y (kepuasan pelanggan)

Sumber: Hasil Olah Data SPSS 24

Berdasarkan Tabel 9 menunjukkan variabel Manajemen Logistik (X) mempunyai nilai t-hitung sebesar 6,327. Nilai t tabel yang merupakan standar untuk mengambil keputusan pada hipotesis dicari dengan menentukan df. Nilai $\mathrm{df}=\mathrm{n}-\mathrm{k}, \mathrm{n}$ adalah jumlah responden dan $\mathrm{k}$ adalah jumlah semua variabel dalam penelitian ini $(\mathrm{df}=\mathrm{n}-\mathrm{k}=50-2=48)$, diperoleh nilai $\mathrm{t}$ tabel pada tingkat signifikansi 0,05 yaitu sebesar 2,01.

Pada penelitian ini terdapat hipotesis: 
$\mathrm{H}_{0}=$ Tidak terdapat pengaruh antara Manajemen Logistik terhadap Tingkat Kepuasan Pelanggan.

$\mathrm{H}_{1}=$ Terdapat pengaruh antara Manajemen Logistik terhadap Tingkat Kepuasan Pelanggan.

Hasil analisis menunjukkan nilai $t_{\text {hitung }}>t_{\text {tabel }}(6,327>2,01)$. Hal ini berarti $H_{o}$ ditolak dan $H_{1}$ diterima, atau terdapat pengaruh (secara parsial) antara Manajemen Logistik terhadap Tingkat Kepuasan Pelanggan.

\subsection{Uji regresi linier sederhana}

\section{Coefficients $^{\mathrm{a}}$}

Tabel 10. Hasil Uji Regresi Linier Sederhana

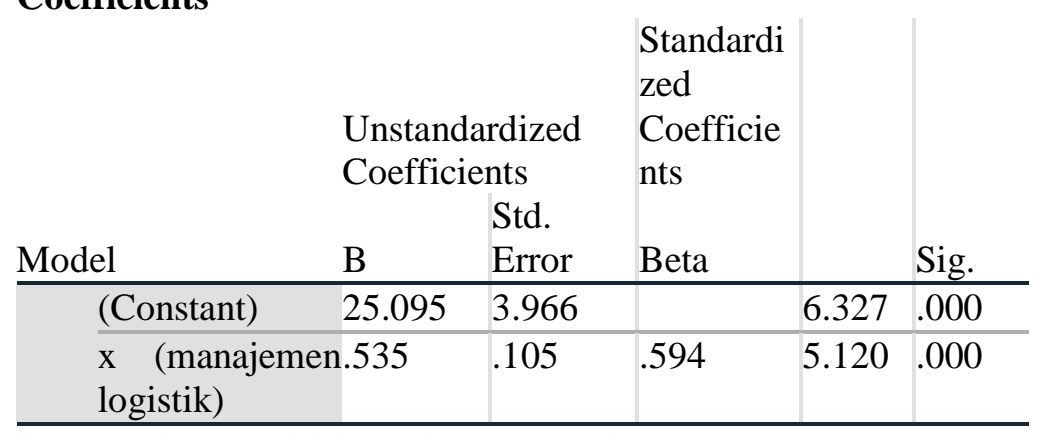

a. Dependent Variable: y (kepuasan pelanggan)

Sumber : Hasil Olah Data SPSS 24

Dari Tabel 10 di atas (kolom B) diperoleh persamaan regresi linier sederhana

$$
\mathrm{Y}=\mathbf{2 5 , 0 9 5}+\mathbf{0 , 5 3 5 X}
$$

Keterangan:

$$
\begin{aligned}
& \mathrm{Y}=\text { Tingkat Kepuasan Pelanggan } \\
& \mathrm{X}=\text { Manajemen Logistik }
\end{aligned}
$$

Nilai a $=25,095$ adalah konstanta. Artinya apabila variabel Manajemen Logistik (X) sama dengan nol, maka Tingkat Kepuasan Pelanggan (Y) sebesar 25,095. Diketahui besarnya koefisien regresi Manajemen Logistik (X) diperoleh 0,535 bernilai positif. Hasil tersebut menunjukkan bahwa setiap terjadi peningkatan Manajemen Logistik (X) sebesar satu satuan maka akan diikuti oleh peningkatan Tingkat Kepuasan Pelanggan (Y) sebesar 0,535 satuan, atau sebaliknya apabila terjadi penurunan Manajemen Logistik (X) sebesar satu satuan maka akan diikuti oleh penurunan Tingkat Kepuasan Pelanggan (Y) sebesar 0,535 satuan.

\section{PEMBAHASAN}

Berdasarkan karakteristik responden yang telah mengisi kuesioner yang telah disebar rata-rata pelanggan PT. Bhinneka Bajanas Cab. Cikarang didominasi dengan usia 20-29 tahun dengan presentase 58\%, didominasi oleh pelanggan perempuan dengan presentase 52\%, Pelanggan PT. Bhinneka Bajanas Cab. Cikarang di dominasi pelanggan corporate dengan presentase $74 \%$, dan didominasi pelanggan yang telah bertranskasi dengan PT. Bhinneka Bajanas Cab. Cikarang berkisar 5-10 Thn dengan presentase 36\%.

Selain itu, berdasarkan hasil rekapitulasi dari variabel manajemen logistik didapat rata-rata sebesar 3,78 untuk hal ini hasil rata-rata tersebut masuk kedalam kategori baik, dan sangat disayangkan dari hasil rekapitulasi variabel manajemen logistik masih ada 3 indikator yang nilainya dibawah rata-rata diantaranya: 1) Jasa layanan tambahan yang diberikan PT Bhinneka Bajanas lebih unggul dibandingkan competitor dengan nilai 3,58. 2) PT Bhinneka Bajanas memberikan kenyamanan tempat dalam bertransaksi dan mengambil produk pesanan dengan nilai 3,54.3) PT Bhinneka Bajanas cepat dalam pengiriman produk yang dijual sampai ketangan pelanggan dengan nilai 3,54. Hal ini menunjukkan bahwa manajemen logistik pada PT. Bhinneka Bajanas Cab.Cikarang harus ditingkatkan dan diperbaiki kembali dikarenakan masih ada beberapa indikator yang dibawah rata-rata.

Sedangkan hasil rekapitulasi untuk variabel kepuasan pelanggan didapat rata-rata sebesar 3,8 untuk hal ini hasil rata-rata tersebut masuk kedalam kategori baik, dari hasil rekapitulasi ini masi ada 2 indikator yang dibawah rata-rata diantaranya: 1) Harga barang yang ditawarkan PT. Bhinneka Bajanas lebih murah 
dibandingkan competitor dengan nilai 2,98. 2) Prosedur pembuatan nota tagihan di PT. Bhinneka Bajanas cepat dengan nilai 3,20. Hal ini menunjukkan bahwa kepuasan pelanggan kepada PT. Bhinneka Bajanas Cab. Cikarang perlu diperbaiki dalam dua indikator tersebut.

Selain itu peneliti juga mengalisa yaitu, pertama uji hipotesis yang terdiri dari hasil uji koefisien korelasi, uji koefisien determinasi, uji regresi linear sederhana, uji t. Dan hasil uji tersebut peneliti mengetahui besar pengaruh variabel manajemen logistik terhadap variabel kepuasan pelanggan, hasil penghitungan dari kuesioner yang merupakan r-Hitung, kemudian dibandingkan dengan r-Tabel. Pada penelitian ini, r-Tabel $(\mathrm{n}=50, \mathrm{k}=\mathrm{jumlah}$ semua variabel $=2$, sehingga $\mathrm{n}-2=50-2=48)$ pada tingkat signifikansi 0,05 , menunjukkan $\mathrm{r}-$ Tabel sebesar 0,2787. Pada Tabel di atas, seluruh nilai korelasi atau r-hitung setiap pertanyaan lebih dari nilai r-Tabel $(0,2787)$. Hal ini berarti hasil pengujian validitas menunjukkan semua data valid.

Kedua, melakukan pegujian korelasi, Koefisien Korelasi (R) sebesar 0,594. Nilai tersebut menunjukkan bahwa pengaruh variabel Manajemen Logistik adalah terhadap Tingkat Kepuasan Pelanggan adalah kuat. Ketiga, melakukan pengujian koefisien determinasi, Sedangkan koefisien determinasi (R2) menunjukkan nilai $\mathrm{R} 2=0,353$. Artinya variabel Manajemen Logistik (X) dapat menerangkan atau menjelaskan Tingkat Kepuasan Pelanggan (Y) sebesar 35,3\%, sisanya sebesar 64,7 \% (dari penghitungan 100\%-35,3\%) dipengaruhi oleh variabel lain yang tidak termasuk dalam model atau persamaan pada penelitian ini.

Keempat, melakukan pengujian regresi linear sederhana dan uji t dimana, Nilai a $=25,095$ adalah konstanta. Artinya apabila variabel manjemen logistik (X) sama dengan nol, maka Tingkat Kepuasan Pelanggan (Y) sebesar 25,095. Diketahui besarnya koefisien regresi Manajemen Logistik (X) diperoleh 0,535 bernilai positif. Hasil tersebut menunjukkan bahwa setiap terjadi peningkatan Manajemen Logistik (X) sebesar satu satuan maka akan diikuti oleh peningkatan Tingkat Kepuasan Pelanggan (Y) sebesar 0,535 satuan, atau sebaliknya apabila terjadi penurunan Manajemen Logistik (X) sebesar satu satuan maka akan diikuti oleh penurunan Tingkat Kepuasan Pelanggan (Y) sebesar 0,535 satuan. Dan uji t menunjukkan variabel Manajemen Logistik (X) mempunyai nilai t-hitung sebesar 6,327. Nilai t tabel yang merupakan standar untuk mengambil keputusan pada hipotesis dicari dengan menentukan df. Nilai $\mathrm{df}=\mathrm{n}-\mathrm{k}, \mathrm{n}$ adalah jumlah responden dan $\mathrm{k}$ adalah jumlah semua variabel dalam penelitian ini $(\mathrm{df}=\mathrm{n}-\mathrm{k}=50-2=48)$, diperoleh nilai $\mathrm{t}$ tabel pada tingkat signifikansi 0,05 yaitu sebesar 2,01. Pada penelitian ini terdapat hipotesis:

$\mathrm{H} 0=$ Tidak terdapat pengaruh antara Manajemen Logistik terhadap Tingkat Kepuasan Pelanggan.

H1= Terdapat pengaruh antara Manajemen Logistik terhadap Tingkat Kepuasan Pelanggan.

Hasil analisis menunjukkan nilai $t$ hitung $>t$ tabel $(6,327>2,01)$. Hal ini berarti Ho ditolak dan $\mathrm{H} 1$ diterima, atau terdapat pengaruh (secara parsial) antara Manajemen Logistik terhadap Tingkat Kepuasan Pelanggan. Hasil penelitian ini memberikan pandangan bahwa manajemen logistik berpengaruh terhadap kepuasan pelanggan hal ini dapat dilihat pula dalam penelitian sebelumnya yang dilakukan oleh Raymond Hendry dan Yohji Ericko (2015) mengenai "Pengaruh logistik service quality terhadap kepuasan dan loyalitas konsumen kentucky fried chicken di surabaya" Berdasarkan hasil evaluasi bahwa hasil penelitian yang dilakukan menunjukkan bahwa ketiga variabel saling berpengaruh.

\section{KESIMPULAN}

Berdasarkan hasil analisis yang telah dilakukan, maka peneliti dapat mengambil kesimpulan, yaitu hasil penelitian ini menunjukkan $\left(R^{2}\right)$ menunjukkan nilai $R^{2}=0,353$. Artinya variabel Manajemen Logistik (X) dapat menerangkan atau menjelaskan Tingkat Kepuasan Pelanggan (Y) sebesar 35,3\%, sisanya sebesar 64,7 \% (dari penghitungan 100\%-35,3\%) dipengaruhi oleh variabel lain yang tidak termasuk dalam model atau persamaan pada penelitian ini.

\section{DAFTAR PUSTAKA}

[1] Abdul, F. W. (2016). IMPROVING SERVICE QUALITY OF CALL CENTER USING DMAIC METHOD AND SERVICE BLUEPRINT, Journal of Management and Business, 15(1), 35-48.

[2] Abdul, F. W., Iridiastadi, H. (2018). Perbaikan dan Peningkatan Kualitas Pelayanan Control, Jurnal Administrasi Kantor, 6(1), 1-10.

[3] Hendry, R. \& Ericko, Y. (2015). Pengaruh Logistic Service Quality Terhadap Kepuasan dan Loyalitas Konsumen Kentucky Fried Chicken di Surabaya, Jurnal Hospitality dan Manajemen Jasa, 3(2), 574-586. 
[4] Kotler, Philip dan A.B Susanto. 2000. Manajemen Pemasaran Jasa Di Indonesia Analisis Perencanaan, Implementasi, dan Pengendalian. Jakarta: Salemba Empat Jakarta

[5] Remenusa, O. (2013). Kualitas Layanan dan Kepuasan Pelanggan pengaruhnya tehadap Loyalitas Pelanggan Pada PT. DGS Manado, Jurnal EMBA, 1(3), 1193-1202.

[6] Siagian, M. Yolanda. (2005). Aplikasi Supply Chain Management dalam dunia bisnis. Jakarta: PT. Grasindo Jakarta

[7] Tjiptono, Fandy. 2014. Pemasaran Jasa (Prinsip, Penerapan, Penelitian). Yogyakarta: Cv. Andi Offset Yogyakarta

[8] Utami, N., \& Sitorus, O., F. (2015). Manajemen Logistik di Giant Ekstra, Jurnal Utilitas, 1(1), 92-103. 